\title{
Role of biliary stenting in the management of bile duct stones in the elderly
}

Nearly a third of patients with common bile duct stones are at risk of developing recurrent cholangitis or pancreatitis. ${ }^{1}$ These complications carry a significant mortality in elderly, infirm patients so that prompt intervention to clear the duct of stones (or at least establish an uninterrupted flow of bile) is, particularly important.

Endoscopic sphincterotomy and basket extraction is the initial treatment of choice for a patient of any age with choledocholithiasis, which clears the bile duct of stones in up to $90 \%{ }^{2-4}$ Elderly patients in whom sphincterotomy and basket extraction is unsuccessful present a challenging clinical problem, as surgical exploration carries an unacceptably high mortality. ${ }^{56}$ Many alternative therapeutic approaches in those few patients in whom sphincterotomy and basket extraction is unsuccessful, include:- surgical exploration, mechanical lithotripsy, extracorporeal shock wave lithotripsy (ESWL), contact dissolution, electrohydraulic and laser lithotripsy, and stenting.

\section{Surgical exploration}

Surgical exploration of the common bile duct is well tolerated by young, fit patients where the death rate is about $1 \%$ or less. ${ }^{7-9}$ In elderly and infirm patients the death rate may be as high as $10 \%$ or more, ${ }^{710}$ which makes surgery an unattractive proposition, particularly in patients with significant concomitant cardiorespiratory disease.

\section{Mechanical lithotripsy}

Using a conventional Dornier basket, successful endoscopic extraction of common bile duct stones is unpredictable for stones greater than $15 \mathrm{~mm}$ diameter and mechanical lithotripsy offers an alternative approach. ${ }^{11}$ This is performed using an endoscopically placed crushing basket. Several different designs are now available. The success rate using this technique can be as high as $80-90 \% \%^{12-15}$ although several attempts are often required. The successful application of this technique seems to be inversely proportional to stone size as it is difficult to entrap very large stones within the basket. The success rate may be as low as $25 \%$ in stones with a diameter exceeding $25 \mathrm{~cm} .{ }^{11}$ Stones situated above a stricture also present difficulties.

\section{Extracorporeal shock wave lithotripsy (ESWL)}

ESWL fragments large stones using high pressure waves generated by spark gap, piezoelectric laser of electromagnetic generation. This method of treatment clears retained bile duct stones in $60-90 \%$ of patients, although some patients require repeated treatments. ${ }^{16-21}$ Mortality associated with ESWL ranges from $0-2 \%$. Major adverse effects are uncommon even in the elderly. ${ }^{16-21}$.

Cost is the major drawback with ESWL, particularly as there are several cheap and equally effective non- surgical alternatives. Furthermore, capital investment in ESWL is becoming even less attractive because laparoscopic cholecystectomy is rapidly reducing the indications for ESWL in biliary disease in general.

\section{Contact dissolution}

Direct application of solvents such as mono-octanoin and methyl-tert-butyl-ether through a nasobiliary drain is much less effective in clearing bile duct stones ${ }^{22-26}$ than stones in the gall bladder. The success rate for bile duct stones is about $30 \%{ }^{2627}$ The technique has not gained widespread popularity and its future remains in doubt because of these poor results, the labour intensive nature of contact dissolution therapy, and significant side effects including drowsiness, diarrhoea, and nausea.

\section{Electrohydraulic and laser lithotripsy}

These techniques are still under evaluation in specialist units. The basic principle is to set up a shock wave in the stone by direct contact with a high voltage discharge (electrohydraulic lithotripsy) or a pulsed dye laser (laser lithotripsy). These methods of lithotripsy, include the placement of a catheter in the common bile duct under direct vision using a peroral mother and baby scope or a choledochoscope inserted by the percutaneous transhepatic approach. Based on the limited data available, the success rates are $80-100 \%$ for electrohydraulic ${ }^{28-34}$ and $67-88 \%$ for laser lithotripsy. ${ }^{35-37}$ Complications of thermal tissue damage including cholangitis, haemobilia, and bile duct puncture, occur in up to $10 \%$ with the electrohydraulic technique. The death rate is $1 \% .3338$ The place for these techniques is yet to be established. Both are costly and time consuming.

\section{Stents}

Biliary stents are an effective way of establishing free flow of bile in both malignant and non-malignant biliary disease. Stents can be used as a temporary measure in patients with common duct stones in whom simple sphincterotomy and basket extraction has failed, to treat and prevent cholangitis, and to 'buy time' while the duct is cleared using nonsurgical techniques (especially in the elderly) or before elective surgery in young and fit patients. ${ }^{39}$

In addition, there are several studies suggesting that permanent biliary stenting may have a role as a definitive therapy for endoscopically unextractable common duct stones in selected elderly patients who are poor surgical candidates. ${ }^{39-45}$ Such patients, usually with stones $>15$ mm diameter, when followed up long term (mean 16-39 months) after definitive treatment with a stent have had few biliary symptoms (0-25\%). ${ }^{39-45}$ Moreover, when biliary symptoms do recur they can usually be treated conservatively with antibiotics or a stent change, or both. It 
is encouraging that in the series published to date the biliary death rate is remarkably low $(0-10 \%)$. This contrasts with the non-biliary death rate of up to $50 \%$ emphasising that this subgroup of patients is truly 'high risk', and justifies the treatment of their biliary disease as conservatively as possible.

Siegel and Yatto $^{42}$ reported the longterm outcome of pig tail stents as definitive therapy for retained bile duct stones in 22 elderly (mean age 77 years) patients unfit for surgery. All patients had undergone sphincterotomy and a failed attempt at endoscopic stone extraction. Eleven patients had a stricture of the common bile duct in addition to the retained stone(s). After a mean follow up of 16 months, no biliary complications or mortality were noted, but 10 patients had died from non-biliary causes.

Cotton et al ${ }^{43}$ described the outcome in a similar group of elderly (mean age 79 years) high risk patients in whom endoscopic extraction of common duct stones had failed. The mean size of the retained stone(s) was $20 \mathrm{~mm}$ : 12 patients were treated with pig tail and five with 10 French straight stents. After a median follow up of 39 months, two patients required surgery for biliary symptoms. There were five non-biliary but no biliary deaths.

Forty two elderly patients (mean age 83 years) with large $(>15 \mathrm{~mm})$ endoscopically unextractable stones were reported by Cairns et al. ${ }^{39}$ They were treated with 6.5 French pig tail stents and after a mean follow up of 16 months recurrent biliary symptoms occurred in only four patients, all of whom were successfully treated by stent change or antibiotics. These were no biliary deaths and seven non-biliary deaths. No patients required biliary surgery. At the end of follow up, liver function tests were normal in all subjects in whom they were measured.

Soomers et al ${ }^{41}$ reported the longterm outcome of 25 elderly (mean age 81 years) patients with very large $(>25$ $\mathrm{mm}$ ) unextractable stones treated with straight stents. Ten patients were alive and well with no recurrent biliary symptoms after a median follow up of 26 months. Ten patients died of non-biliary causes. Five patients suffered biliary complications, which were successfully treated by surgery or stent change.

Straight stents were also used in another study of 15 elderly (mean age 81 years) patients with large unextractable common duct stones. ${ }^{44}$ After a mean follow up of 24 months, there were no biliary complications or deaths, but eight of the patients had died from non-biliary causes.

More recently, Peters et $a l^{45}$ reported a group of 40 elderly (mean age 76 years) patients treated with stents for common duct stones. Of these patients the stent placement was considered as definitive treatment in 27 . There was a median of two stones of $15 \mathrm{~mm}$ diameter. Seven French pig tail stents were used in all patients except five (who had an associated stricture) in whom 10 French straight stents were used. After a median follow up of 13 months, 23 of 40 patients remained asymptomatic. The overall death rate was $15 \%$, with two biliary and four nonbiliary deaths. The longterm biliary complication rate was $20 \%$ and occurred only in those patients with an intact gall bladder. Cholangitis occurred in three patients, all of whom had not had a sphinterotomy.

Most of the studies have used 6-8 French guage pig tail stents because, compared with straight stents, they probably cause less problems in terms of stent migration and perforation, ${ }^{39}$ in the setting of bile duct stones and an existing sphincterotomy. In addition, they can be inserted through the smaller diagnostic duodenoscope. In the series of patients that we have reported, however, in which 10 French straight stents were used, no problems with stent migration were seen. ${ }^{44}$ Furthermore, straight stents are probably at least as effective as pig tail stents in terms of biliary symptoms and mortality. ${ }^{41} 43-45$

Even though the stent is left in situ over many months or years, stent blockage does not seem to be a problem perhaps because in patients with large common bile duct stones, the stent works by splinting the stones or preventing impaction in the distal common bile duct or both, thus ensuring free flow of bile. The patency or otherwise of the stent itself is, therefore, not so relevant to achieving a successful result. If stents work by splinting the stones in the common bile duct then it follows that the diameter of the lumen of the stent is not important. There is no evidence so far that 10 French stents are superior to stents of smaller diameter. ${ }^{39-45}$

What is the place of sphincterotomy in these patients? Clearly, if the stones are small $(\leqslant 15 \mathrm{~mm})$, endoscopic extraction should be attempted after sphincterotomy. Our current practice is the early use of a stent as definitive treatment in elderly infirm patients with very large stones $(>20$ $\mathrm{mm}$ ). A sphincterotomy may not always be necessary in these patients. Although there is some limited evidence to suggest that patients who have not had a sphincterotomy are at slightly increased risk of subsequently developing cholangitis, ${ }^{45}$ this has to be balanced against the short term risk of the sphincterotomy itself.

The success of stents as measured by freedom from biliary symptoms and low biliary mortality, is comparable with mechanical lithotripsy and ESWL and probably also to electrohydraulic and laser lithotripsy. Stents are superior to contact dissolution therapy and are the treatment of choice for the comparatively uncommon problem of a stricture below common bile duct stones. The main advantage of stenting over these other non-surgical techniques for the high risk elderly patients is that stenting is cheaper and quicker because it can be performed at one sitting. Furthermore, stenting is widely available, requires no additional equipment or operator training, and offers an effective treatment of bile duct stones in selected elderly patients.

Academic Unit of Medicine,

H R DALTON St Fames's University Hospital, Leeds LS9 7TF

Gastroenterology Unit,

Fohn Radcliffe Hospital,

Oxford OX3 9DU

1 Neoptolemos JP, Davison BR, Shaw DE, et al. Study of common bile duct exploration and endoscopic sphincterotomy in a consecutive series of $\mathbf{4 3 8}$ patients. Br 7 Surg 1987; 74: 916-21.

2 Cotton PB. Endoscopic management of bile duct stones. Gut 1984; 25: 587-97.

3 Cotton PB, Vallon AG. British experience with duodenoscopic sphincterotomy for removal of the bile duct stones. Br $\mathcal{F}$ Surg 1982; 68: 373-5.

4 Vaira D, Ainley C, Williams S, et al. Endoscopic sphincterotomy in 1000 consecutive patients. Lancet 1989 ; i: $431-4$.

5 Sullivan DM, Ruffin-Hood T, Griffin WO. Biliary tract surgery in the elderly. Am $\mathcal{F}$ Surg 1982; 143: 218-20.

6 Vellacott KD, Powell PH. Exploration of the common bile duct: a comparative study. $B r \mathcal{F}$ Surg 1979; 66: 389.

7 Johnson AG, Hoskings SW. Appraisal of the management of bile duct stones. Br f Surg 1987; 74: 555-60.

8 Heberer G, Sackmann M, Krämling H-J, Sauerbruch T, Paumgartner G. The place of lithotripsy and surgery in the management of gallstone disease. Adv Surg 1990; 23: 291-315.

9 Pappas TN, Slimane TB, Rooks DC. 100 consecutive common duct explorations without mortality. Ann Surg 1990; 211: 259-62.

$10 \mathrm{McSh}$ erry CK, Glenn F. The incidence and causes of death following surgery for non-malignant biliary tract disease. Ann Surg 1980;191: 271-5. surgery for non-malignant biliary tract disease. Ann Surg 1980; 191: 271-5.
Classen M, Hagenmuller F, Knyrim K, Frimberger E. Giant bile duct Classen M, Hagenmuller F, Knyrim K, Frimberger E. G
stones - non-surgical treatment. Endoscopy 1988; 20: 21-6.

12 Schneider MJ, Matek W, Bauer R, Domschke W. Mechanical lithotripsy of bile duct stones in 209 patients: effect of technical advances. Endoscopy 1988; 20: 248-53.

13 Riemann JF, Demling L. Lithotripsy of bile duct stones. Endoscopy 1983; 15: 191 .

14 Staritz M, Ewe K, Mayer zum Buschenfelde KH. Mechanical gallstone lithotripsy in the common bile duct: in vitro and in vivo experience. Endoscopy 1983; 15: 316 .

15 Siegel JH, Ben-Zvi JS, Pullano WE. Mechanical lithotripsy of common duct stones. Gastrointest Endosc 1990; 36: 351-6.

16 Sauerbruch T, Stern $M$. Fragmentation of bile duct stones by extracorporeal shock waves. Gastroenterology 1989; 96: 146-52. 
17 Bland KI, Jones RS, Maher JW, et al. Extracorporeal shock wave lithotripsy of bile duct calculi. Ann Surg 1989; 209: 743-55.

18 Merrett MN, Desmond PV. Extracorporeal shock wave lithotripsy for bile duct stones: an Australian experience. $\mathcal{F}$ Gastroenterol Hepatol 1990; 5: 537-41.

19 Sauerbruch T, Holl J, Sackmann M, Paumgartner G. Fragmentation of bile duct stones by extracorporeal shock wave lithotripsy. A five year experiduct stones by extracorporeal shock

20 den Toom R, Nijs HGT, van Blankenstein M, et al. Extracorporeal shock wave treatment of common bile duct stones: experience with two different lithotripters at a single institution. Br F Surg 1991; 78: 809-13.

21 Lee SH, Fache JS, Burhenne HJ. The value of extracorporeal shock-wave lithotripsy in the management of bile duct stones. Am $\mathcal{F}$ Radiol 1990; 155: 775-9.

22 Murray WR, Laferla G, Fullarton GM. Choledocholithiasis - in vivo dissolution using methyl terbutyl ether (MTBE). Gut 1988; 29: 143-5.

23 Saraya A, Rai RR, Tandon RK. Experience with MTBE as a solvent for common bile duct stones in patients with tube in situ. $\mathcal{f}$ Gastroenterol Hepatol 1990; 5: 130-4.

24 Gayle GL, Summerfield JA, McIntyre N, Dooley JS. Methyl terbutyl ether dissolution for common bile duct stones. F Hepatol 1990; 10: ether dissol

25 Dipadova D, Dipadova F, Montorsi W, Tritapepe R. MTBE fails to dissolve retained radiolucent common bile duct stones. Gastroenterology 1986; 91 : 1296-300.

26 Palmer KR, Hoffman AF. Intraductal mono-octanion for the direct dissolution of bile duct stones: experience in 343 patients. Gut 1986; 27: 196-202.

27 Allen M, Broody TI, Thistle IL, et al. Cholelithiasis using methyl-tert-butyl ether. Gastroenterology 1985; 88: 122-5.

28 Ligoury CL, Bonnel D, Canard JM, Cornud F, Dumont JL. Intracorporeal electrohydraulic shock-wave lithotripsy of common bile duct stones: preliminary results in 7 cases. Endoscopy 1987; 19: 237-40.

29 Picus O, Weyman PJ, Marx MV. Role of percutaneous intracorporeal electrohydraulic lithotripsy in the treatment of biliary tract calculi. Radiology 1989; 170: 989-93.

30 Yoshimoto H, Ikeda S, Tanaka M, Matsumoto S, Kuroda Y. Choledochoscopic electrohydraulic lithotripsy and lithotomy for stones in the common bile duct, intrahepatic ducts and gallbladder. Ann Surg 1989; 210: $576-82$.

31 Leung JWC, Chung SSC. Electrohydraulic lithotripsy in peroral choledochoscopy. BMF 1989; 299: 595-8.

32 Seigel JH, Ben-Zvi JS, Pullano WE. Endoscopic electrohydraulic lithotripsy. Gastrointest Endosc 1990; 36: 134-6.

33 Akiyama $\mathrm{H}$, Okazaki T, Takashima I, et al. Percutaneous treatments for biliary diseases. Radiology 1990; 176: 25-30.

34 Chen MF, Jan YY. Percutaneous transhepatic cholangioscopic lithotripsy. Br f Surg 1990; 77: 530-2.

35 Ell C, Lux G, Hochberger J, Muller D, Demling L. Laserlithotripsy of common bile duct stones. Gut 1988; 29: 746-51.

36 Cotton PB, Kozarek RA, Schapiro RH, et al. Endoscopic laser lithotripsy of large bile duct stones. Gastroenterology 1990; 99: 1128-33.

37 Ponchon T, Gagnon P, Valette PJ, et al. Pulsed dye laser lithotripsy of bile duct stones. Gastroenterology 1991; 100: 1730-6.

38 Jeng KS, Chiang HS, Shih SC. Limitations of percutaneous transhepatic cholangioscopy in the removal of complicated biliary calculi. World $\mathcal{f}$ Surg 1989; 13: 603-10.

39 Cairns SC, Dias L, Cotton PB, Salmon PR, Russell ROG. Additional endoscopic procedures instead of urgent surgery for retained common bile duct stones. Gut 1989; 30: 535-40.

40 Kill J, Kruje A, Rokkjaer M. Large bile duct stones treated by endoscopic biliary drainage. Surgery 1989; 105: 51-6.

41 Soomers AJ, Nagengast EM, Yap SH. Endoscopic placement of biliary endoprosthesis in patients with endoscopically unextractable common bile duct stones: a long term follow up of 26 patients. Endoscopy 1990; 22: 24-6.

42 Siegel JH, Yatto RP. Biliary endoprostheses for the management of retained common bile duct stones. Am f Gastroenterol 1984; 79: 50-4.

43 Cotton PB, Forbes A, Leung JWC, Dineen L. Endoscopic stenting for longterm treatment of large bile duct stones: 2 to 5 year follow-up. Gastrointest Endosc 1987; 33: 411-2.

44 Dalton HR, Merrett MN, Barr H, Britton BJ, Chapman RWG. Endoscopically placed biliary stents for impacted common bile duct Endoscopically placed biliary stents for impacted

45 Peters R, Macmathuna P, Lombard M, Karani J, Westaby D. Management of common bile duct stones with a biliary endoprosthesis: report on 40 cases. Gut 1992; 33: 1412-5. 